\title{
The Copperbelt model of integrated care for survivors of rape and defilement: Testing the feasibility of police provision of emergency contraceptive pills
}

Jill Keesbury

Population Council

Mary Zama

Population Council

Sudha Shreeniwas

Follow this and additional works at: https://knowledgecommons.popcouncil.org/departments_sbsr-rh

Part of the Demography, Population, and Ecology Commons, Domestic and Intimate Partner Violence Commons, Family, Life Course, and Society Commons, International Public Health Commons, and the Medicine and Health Commons

How does access to this work benefit you? Let us know!

\section{Recommended Citation}

Keesbury, Jill, Mary Zama, and Sudha Shreeniwas. 2009. "The Copperbelt model of integrated care for survivors of rape and defilement: Testing the feasibility of police provision of emergency contraceptive pills," Final report. Lusaka: Population Council. 


\section{The Copperbelt Model of Integrated Care for Survivors of Rape and Defilement}

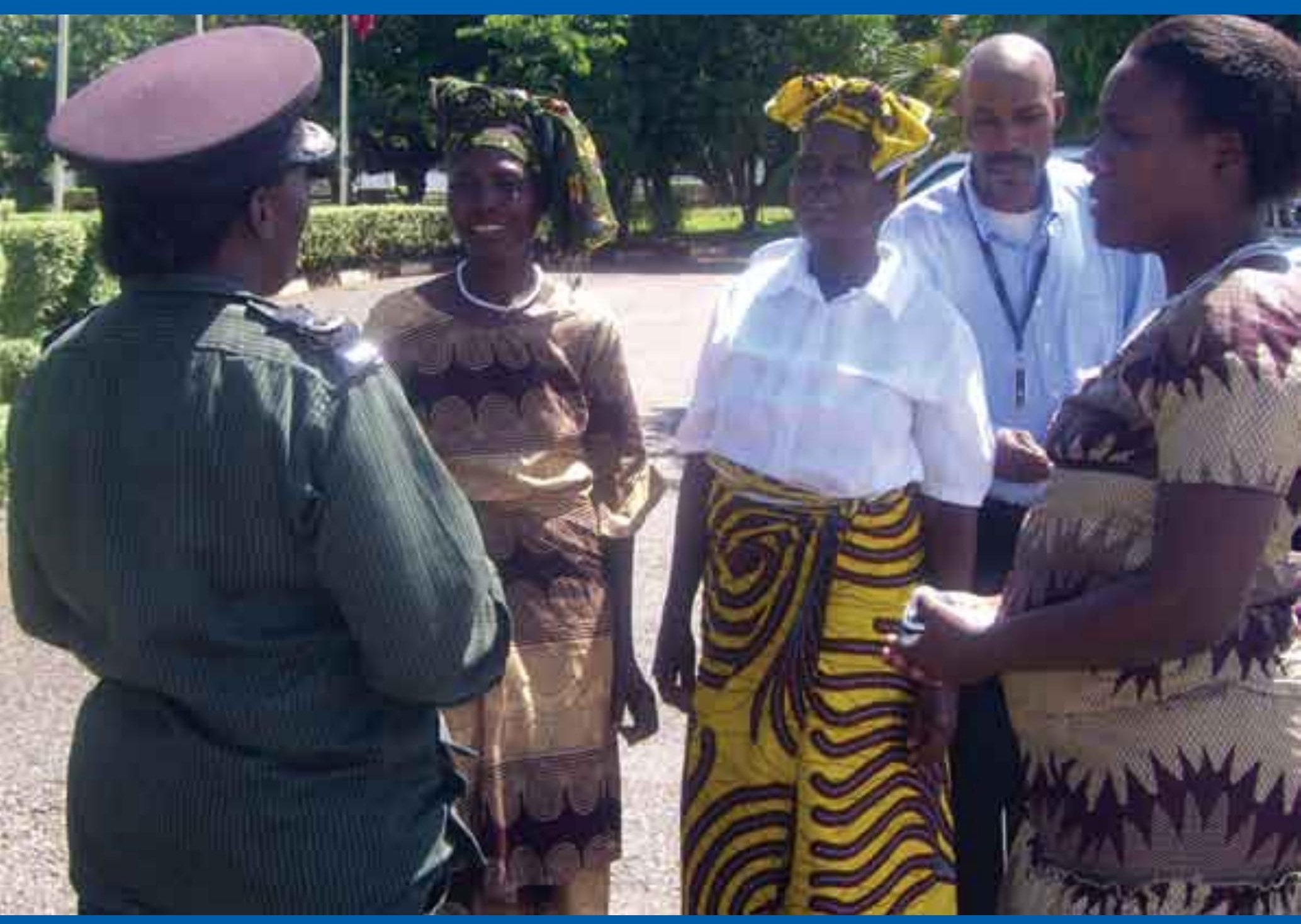

Testing the Feasibility of Police Provision of Emergency Contraceptive Pills 



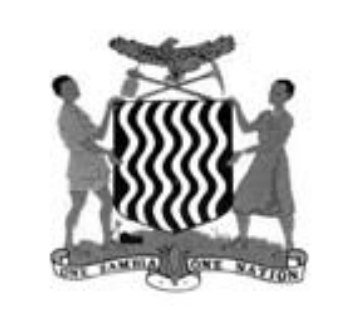

\section{The Copperbelt Model of Integrated Care for Survivors of Rape and Defilement:}

\section{Testing the Feasibility of Police Provision of Emergency Contraceptive Pills}

Jill Keesbury, Population Council Zambia Mary Zama, Population Council Zambia Sudha Shreeniwas, Independent Consultant
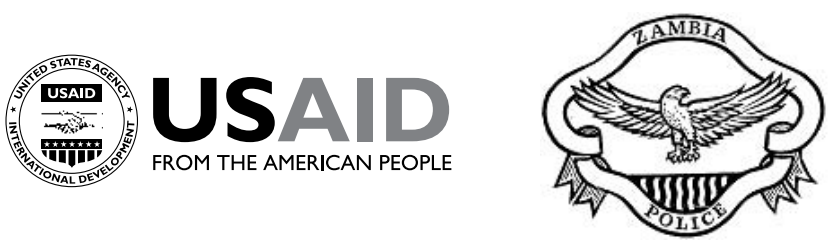

(1) Population Council

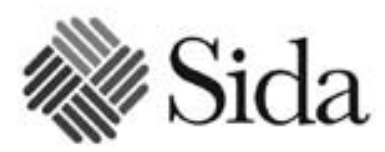




\section{Acknowledgements}

This study would not have been possible without the support and vision of the Government of Zambia. The Zambian Police Service supported the study at all levels, from the National Coordinator to the dedicated Victim Support Unit (VSU) Officers in the field. Mr. Peter Kanunka was instrumental in establishing the study during his tenure as National VSU Coordinator and his successors Ms. Susan Malundu and Ms. Betty Ngulube Timba, helped to sustain the intervention. The Copperbelt Divisional Community Services and VSU Coordinator, Mr. Stephen Simisuku, was actively involved in the project from its inception, co-facilitating the initial classroom trainings and conducting routine supervisory visits in conjunction with Ndola district health staff.

The Ministry of Health demonstrated equal commitment to the study. The Director of Public Health and Research, Dr. Victor Mukonka, supported this work from its inception. Dr. Reuben Mbewe, the national Reproductive Health Specialist, availed EC stocks for the study and championed the work at the national-level. The Copperbelt Provincial Health Director, Dr. Chandwa N'gambi, demonstrated true commitment to improving rape and defilement care in the province, and worked closely with the study coordinator to strengthen services. The Directors of Ndola Central Hospital and Arthur Davidson Children's Hospital demonstrated similar commitment to providing quality, affordable care to survivors of sexual violence.

The study was actively guided by a steering committee which was led by the Office of the Copperbelt Provincial Health Director, and consisted of representatives from the Ministries of Education, Community Development and Social Services, Health, Home Affairs (Zambia Police VSU), YWCA, Catholic Diocese and participating communities.

Partners such as UNICEF, UNFPA, Care International in Zambia, and the Government's Gender-in-Development Division also helped promote this work at the national level. The study was conceived and initially implemented under the guidance of John Skibiak.

The study benefited from financial support from the Swedish-Norwegian HIV/AIDS Team in Africa, the Hewlett Foundation, and USAID/Zambia.

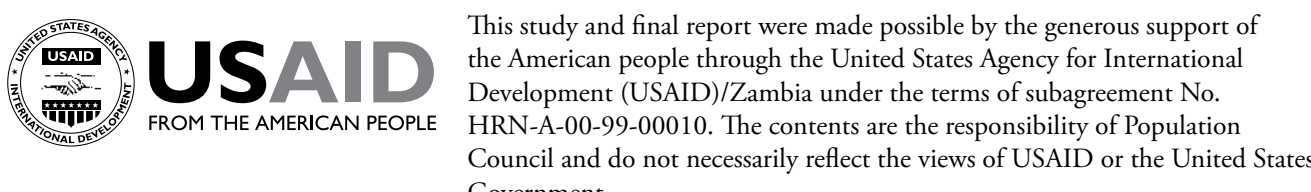
Government.

\footnotetext{
(1) Population Council

The Population Council conducts research worldwide to improve policies, programs, and products in three areas: HIV and AIDS; poverty, gender, and youth; and reproductive health.
}

Published: October 2009

La Belva Court, Plot 417 Chindo Road, Kabulonga, Lusaka 10101, Zambia; Tel: +260-211-262-665/6 www.popcouncil.org

Suggested citation: Keesbury, Jill, Mary Zama, and Sudha Shreeniwas. 2009. "The Copperbelt Model of Integrated Care for Survivors of Rape and Defilement: Testing the feasibility of police provision of emergency contraceptive pills." Lusaka: Population Council.

(C) 2009 The Population Council, Inc.

Any part of this publication may be photocopied without permission from the publisher provided that copies are distributed without charge and that full source citation is provided. The Population Council would appreciate receiving a copy of any materials in which the text is used. 


\section{EXECUtIVe Summary}

From 2005-2008, the Zambian Ministry of Home Affairs (Police Service), Ministry of Health $(\mathrm{MOH})$ and Population Council collaborated on an operations research study designed to improve services for survivors of genderbased violence (GBV). Specifically, the study tested the feasibility of police provision of emergency contraception (EC), a contraceptive method which prevents unwanted pregnancy within 120 hours of unprotected sex. It also hypothesized that the intervention could strengthen GBV services at both police and health facilities through an increased emphasis on multi-sectoral collaboration.

Under the intervention, Victim Support Unit (VSU) officers were trained to deliver EC to eligible survivors of sexual violence (rape and defilement), and to refer survivors to health facilities for appropriate clinical management and forensic evidence collection. To ensure the quality and safety of such services, VSU officers were trained under the Ministry of Health's Community-Based/ Employer-Based Family Planning Distributor curriculum, and oversight was provided by a health provider. The study was implemented in five police stations in the Copperbelt's Ndola district and guided by a multi-sectoral steering committee.

The study was evaluated through service provision data, a provider knowledge, attitudes and practices survey and focus group discussions. Major findings included:

- Police can safely and effectively provide EC. Over the life of the intervention, trained VSU officers provided a total of 357 doses of EC to survivors of sexual violence. No adverse events or incidents of misuse were reported. Health sector staff were pleased with the intervention, noting that "we haven't faced any challenges regarding these EC being administered by police officers. If any, it has made our job easy because by the time survivors come to the hospital, they already have received some help so we just pick up from where our friends ended."

- Reporting of sexual violence cases increased by 48 percent in participating police stations from 2006 to 2007, and community members noted that "Now we quickly report to the police because we know we will find assistance like EC."

- Trained VSU officers consistently referred survivors for other health services, including post-exposure prophylaxis for HIV, with three of the five intervention sites reporting referral rates of 95 percent or higher.

- The program was perceived by provincial management as successful, sustainable and cost-effective. According to one official, "this program is resource cheap in the sense that it doesn't need a lot of funds to be sustained; keeping in mind that the most expensive part of sustainability of such programs is manpower which we partly have in an already existing system." 
Based on these findings, national scale-up of this program has been widely endorsed. The following recommendations are offered to guide such scale-up:

- Ensure that a dedicated EC pill is available through the public sector;

- Incorporate police provision of EC into provincial, national policies and guidelines;

- Integrate EC services into the national VSU training curriculum and offer $\mathrm{MOH}$ certification;

- Refine the EC provision training curriculum in conjunction with the $\mathrm{MOH}$;

- Integrate EC into the national training curriculum for all police officers;

- Assign dedicated health sector staff to support police EC providers; and

- Develop innovative approaches to overcoming transport constraints. 


\section{Contents}

$\begin{array}{ll}\text { AcKNOWLedgements } & \text { ii }\end{array}$

EXecutive Summary

1. Introduction and Research Questions 1

2. Designing a Response to GBV 4

$\begin{array}{ll}\text { 3. THE INTERVENTION } & 7\end{array}$

4. Evaluation Methodology 14

5. Results: Service Statistics 16

6. Results: Provider KAP survey 20

7. RESULTS: KIls AND FGDs 22

8. ReCOMmENDATIONS $\quad 30$

Appendix 1: Training Schedule for VSU Officers 34

Appendix 2: Client Screening Checklist for Police Provision of EC $\quad 35$ 


\section{Introduction and Research Questions}

Worldwide, an estimated one in every three women will experience some form of gender-based violence (GBV) in their lifetimes. ${ }^{i}$ Defined broadly, GBV includes all forms of physical, psychological and sexual violence that are related to the victim's gender or gender role in a society or culture. ${ }^{\text {ii }}$ This study focuses specifically on one form of GBV, sexual violence (SV), defined under Zambian law as rape of adult women or defilement of children under the age of 16 .

GBV as a whole is a stigmatized and emotionally-charged issue in Zambia, as it is in many African countries. Only recently has it emerged a matter of public debate, benefitting from the attention given by the former First Lady, Mrs. Maureen Mwanawasa. While public recognition of GBV is growing in the country, reliable data on the nature and extent of such violence is limited. The 2007 Demographic and Health Survey (DHS) gives some insight into prevalence of physical and sexual violence in the country, although it is widely believed to be an underestimate due to methodological constraints. The survey demonstrates that Zambian women experience higher rates of physical violence than their counterparts in Malawi and Kenya, and that husbands or other intimate partners are the most common perpetrators of such violence. DHS data also finds that 20 percent of Zambian women between the ages of 15 and 49 have ever experienced some form of sexual violence. This proportion does not take into account sexual violence occurring to girls younger than 15 .

\begin{tabular}{|c|c|c|c|c|c|c|c|}
\hline \multirow[t]{2}{*}{ Country } & \multirow[t]{2}{*}{ Data source } & \multirow[t]{2}{*}{$\begin{array}{c}\text { Ever } \\
\text { experienced } \\
\text { physical } \\
\text { violence* }\end{array}$} & \multirow[t]{2}{*}{$\begin{array}{c}\text { Ever } \\
\text { experienced } \\
\text { sexual } \\
\text { violence* }^{*}\end{array}$} & \multirow[t]{2}{*}{$\begin{array}{c}\text { Violence } \\
\text { perpetrated } \\
\text { by husbandl } \\
\text { partner* }\end{array}$} & \multicolumn{3}{|c|}{$\begin{array}{c}\text { HIV } \\
\text { prevalence }^{* *}\end{array}$} \\
\hline & & & & & Female & Male & Total \\
\hline Kenya & DHS 2003 & 40 & 16 & $57.8^{\dagger}$ & 8.7 & 4.6 & 6.7 \\
\hline Zambia & DHS 2007 & 46.8 & 20.2 & $41.9^{\dagger \dagger}$ & 16.1 & 12.3 & 14.3 \\
\hline Malawi & DHS 2004 & 28 & - & $43.2^{\dagger}$ & 13.3 & 10.2 & 11.8 \\
\hline
\end{tabular}

${ }^{*}$ Question asked of women 15-49 only; **Adults 15-49

${ }^{\dagger}$ Physical violence; ${ }^{\dagger+}$ Sexual violence

A survey conducted by the Population Council in 2007 found that GBV was a common experience among young women in urban Lusaka. Seventy percent of

iHeise, L., Ellsberg, M., and Gottemoeller, M. 1999. "Ending violence against women,"

Population Reports Series L, No. 11.

iiSeries L, No. 11., cited by International Women's Health Coalition, “Triple Jeopardy: Female

Adolescence, Sexual Violence and HIV/AIDS.” June 2008. 
those surveyed said girls in their school were teased or sexually harassed verbally, and 53 percent said girls in their school were sometimes molested, touched or sexually harassed. In terms of forced or coerced sex, 36 percent of respondents had heard of a schoolgirl in their community who was forced to have sex with a teacher, 23 percent had heard of a girl forced to have sex with a classmate, and 48 percent had heard of a girl forced to have sex with a relative from within her household. iii

The risks associated with GBV, especially SV among young women, are numerous and increasingly well-documented. Immediate health consequences include unwanted pregnancy, physical trauma, emotional distress and transmission of HIV. Research indicates that the risk of sero-conversion following forced sex is likely to be higher than following consensual sex, especially among children. ${ }^{\text {iv }}$ The increased violence associated with forced intercourse, and the lack of lubrication, can result in both microscopic and macroscopic mucosal tears. Forced anal penetration is thought to carry a commensurably higher risk of HIV transmission. ${ }^{v}$ The increased risk of infection is especially pronounced in the high HIV-prevalence settings of sub-Saharan Africa. ${ }^{\text {vi }}$ Zambia, which is currently experiencing a generalized HIV epidemic, is particularly at risk of increased transmission due to sexual assault.

\section{A comprehensive response to violence}

There is a growing awareness that GBV requires a multi-sectoral response. The Government of Zambia is currently drafting a set of comprehensive guidelines that outline coordinated responses to be taken by the health, police and social services sectors. The basic elements of such a response, as outlined in Table 2, include clinical management of immediate injuries, police investigation and prosecution, and providing immediate and long-term psychosocial support to survivors.

Central to each sector's response is its ability to coordinate with the other sectors. This is especially pronounced in regard to the police and health services, which are often the first points of contact for the survivors. Within the first 72 hours following an assault, both medical and legal responses are required to ensure the health of the survivor and the ability to prosecute the case. The necessity

\footnotetext{
iiiGWG of USAID. 2006. "Addressing gender-based violence through USAID's health programs: A guide for health sector program officers.” Washington, DC: USAID.

iv Brady, Martha et al. 2009. "Understanding adolescent girls' protection strategies against HIV: An exploratory study in Zambia.” New York: Population Council.

"Speight, C.G. et al. 2006. "Piloting post-exposure prophylaxis in Kenya raises specific concerns for the management of childhood rape." Transactions of the Royal Society of Tropical Medicine and Hygiene.

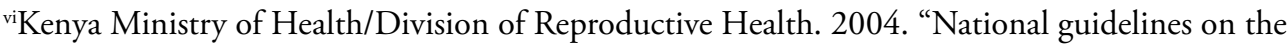
medical management of rape/sexual violence (1st edition).” Nairobi: Kenya.
} 


\begin{tabular}{|ll}
\hline Table 2 Key components of a multi-sectoral response to GBV \\
\hline Sector & Key components of response \\
\hline Health & Pregnancy testing and emergency contraception \\
& - HIV diagnostic testing and counseling and post-exposure prophylaxis \\
& - Evaluation and treatment of injuries, forensic examination and documentation \\
& - Trauma counseling \\
& - Referrals to/from police and social support sectors \\
& - Statement-taking and documentation \\
Police/ Justice & - Investigation of crime scenes \\
& - Collection of forensic evidence and maintaining the chain of evidence \\
& - Ensuring the safety of the victim \\
& - Prosecution of perpetrator \\
& - Referrals to/from health and social support sectors \\
- Provision of safe housing, relocation services \\
- Long-term psychosocial counseling and rehabilitation \\
- Referrals to/from police and health sectors
\end{tabular}

of coordinating medico-legal responses in a limited timeframe makes linkages between these sectors a basic prerequisite for an effective institutional response to GBV.

Emergency contraception (EC) is an essential element of post-rape care which prevents unwanted pregnancy if taken within 120 hours of unprotected sex. .ii $^{\text {vi }}$ EC contains the same hormones as oral contraceptive pills, and can consist of a dedicated product (such as the brands Pregnon or Postinor-2) or high doses of oral contraceptives. Both regimens have been proven to be safe and effective in preventing pregnancy. EC is not an abortifacient and will not harm an existing pregnancy. Stocks of the dedicated product Postinor-2 were donated to the Ministry of Health $(\mathrm{MOH})$ by the Population Council for use in this study, which consist of two pills that are to be taken at a 12-hour interval.

\section{Research questions}

Recognizing the need to strengthen linkages between the police and health sectors, the Zambian Police Service (ZPS) and the MOH undertook an operations research study intended to improve care for survivors of SV. This study was guided by the following research questions:

viiEllis, J.C. et al. 2005. "Introduction of HIV post-exposure prophylaxis for sexually abused children in Malawi," Arch Dis Child 90:1297-1299. 
- Can Victim Support Unit (VSU) officers be trained to safely and effectively provide EC to SV survivors?

- How can linkages, especially in terms of client referrals, between the ZPS and health facilities be improved?

- How can linkages between the ZPS and the community be improved, in order to encourage more reporting of SV cases?

The study took place between 2005 and 2008 in the Ndola district of Zambia's Copperbelt Province. 


\section{Designing a Response to GBV}

\section{Formative research}

In 2005, formative research was conducted to inform the study design. Two types of data were collected. First, a record review was conducted of all SV (legally defined as rape and defilement) cases reporting to police and health facilities in the Copperbelt province. The review included all cases reported in the period between 1 January 2001 and 30 December 2004. A total of 2,203 cases were included in the study from 33 police stations and posts across the province; another 1,077 cases were found in 19 hospitals and health centers across the province. Second, focus group discussions (FGDs) were conducted with community members to assess prevailing perceptions and attitudes that influence care-seeking among sexual violence survivors. Based on the results of the record review, FGDs took place in three communities where reports of GBV were highest: Chingola, Chambishi and Ndola. Respondents were widely sampled from groups in these communities, including: women's groups, health committees, home-based care groups, community development groups, neighborhood watch groups, traditional healers, market women, secondary school students, VSU officers, health care workers and paralegals.

This research demonstrated that the police were often the first, and only, point of contact for SV survivors. Of those who sought institutional support, nearly all (91 percent) reported to the police first. Records indicate that these survivors were inconsistently issued with a Medical Report Form, which must be completed at the hospital and returned to the police with a doctor's signature to begin legal proceedings. Only 45 percent of the forms issued were returned to the police. Less than half as many survivors reported to health facilities $(1,077)$ than to police stations $(2,203)$, suggesting that many who present to the police first do not go on to seek medical care. Community interviews confirmed this, with one FGD participant noting "people usually report to the police first... sometimes a person will go to the hospital first and the doctor will refer them back to the police" before care is provided.

At health facilities, support services for SV survivors were uniformly weak. While 82 percent of survivors arrived within 72 hours of the assault, only 37 percent received EC and 24 percent received post-exposure HIV prophylaxis. Provision of these services was concentrated in a limited number of facilities, and was not consistently or correctly provided to eligible survivors. While few community members were aware of either EC or PEP, they noted that unwanted pregnancy and HIV transmission were the most detrimental consequences of sexual assault. A key barrier to seeking services were the "grey" fees charged at both the health and police facilities for signatures and forms.

Key findings from formative research:

- $91 \%$ of survivors reported to the police first

- $37 \%$ of eligible survivors received EC at hospital

- $24 \%$ of eligible survivors received PEP for HIV

- $74 \%$ of survivors knew the perpetrator

- $27 \%$ of cases were taken to court

- Illegitimate fees of $\mathrm{K} 10,000$ routinely assessed by hospitals and police

Only 27 percent of the cases initially reported to the police were taken to court, despite the fact that 74 percent of survivors indicated that they knew the 
perpetrator. While information was not available on the quality of evidence used in those cases, such a low prosecution rate suggests weaknesses in the collection, storage and documentation of medico-legal evidence.

Research also indicated that survivors were routinely charged illegitimate fees for police and health services. At the police station, survivors were often required to provide 10,000 Kwacha (about 2.50 USD) to cover "photocopy charges" associated with the Medical Report Form. At the health facility, a "signing fee" of 10,000 Kwacha was frequently assessed to ensure that a doctor completed and signed the Medical Report Form. Such fees were identified as a deterrent to seeking services, especially medical care. As noted by one respondent "unfortunately, most people don't go to the hospital because they cannot afford the hospital charges."

\section{Stakeholder's consultation}

Findings from the formative research were presented at a multi-sectoral stakeholder's workshop convened in Ndola. The meeting gathered key stakeholders to systematically review the data and discuss each institution's contribution to the process. The group included 48 participants, who represented the Zambian Ministry of Health, Ministry of Home Affairs (with jurisdiction over the Zambia Police Service), Ministry of Community Development and Social Services, representatives from the provincial offices of these bodies, and various NGOs and churches.

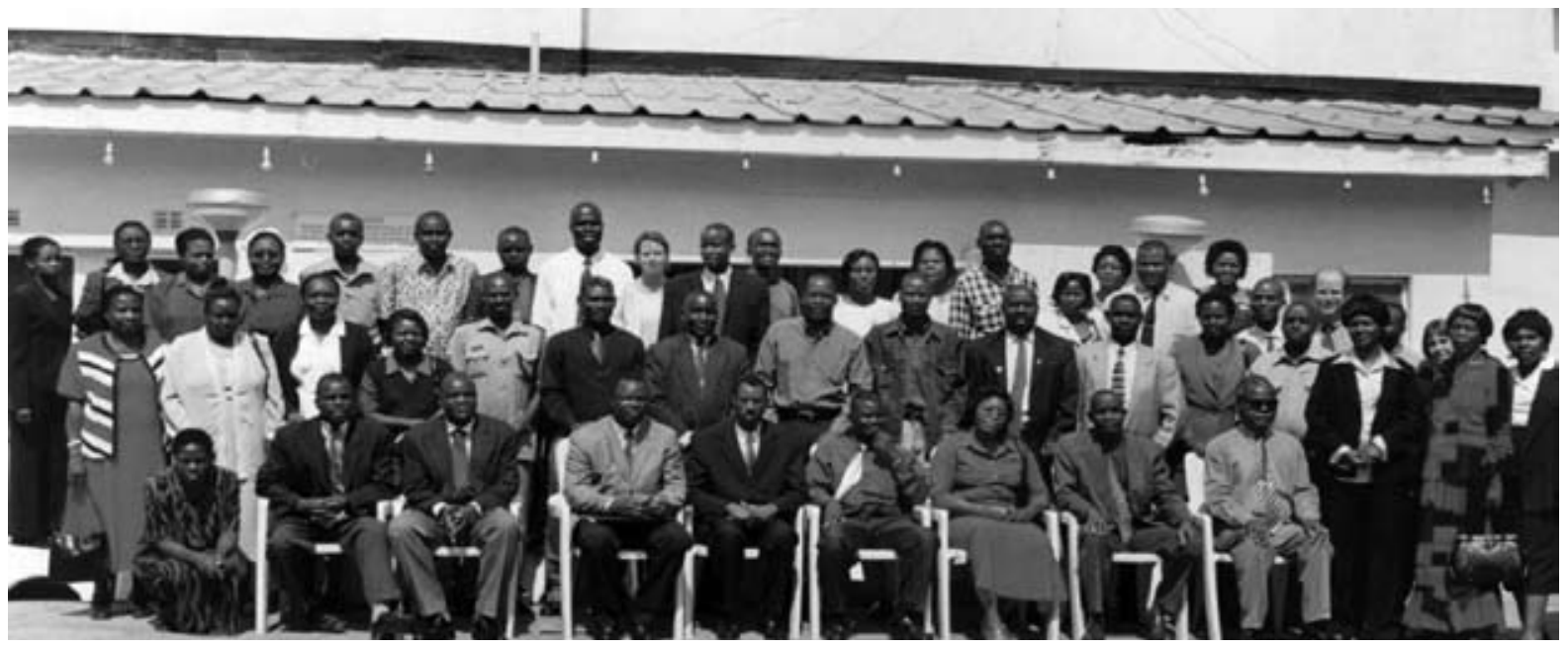

Participants at the Ndola stakeholder's meeting, July 2005

In addition to reviewing the data, participants were 'oriented' on each sector's responses to sexual violence through expert lectures, field trips to corresponding 
institutions and post-visit plenary discussions. The 3-day workshop followed a typical survivor's progression through the criminal, health and legal systems, beginning with a site visit to the police station, then to the hospital and finally to view court proceedings.

At the conclusion of the meeting, participants recommended that measures be undertaken to strengthen the institutional response to sexual violence across all sectors. Noting that the police often serve as the first and only point of contact, it was suggested that special emphasis be placed on improving their capacity to meet survivor's immediate needs and ensure better referral to the health facilities. To do this, they recommended a pilot intervention to strengthen the police service's VSU, which is specifically charged with responding to sexual assault.

Such a pilot would test the feasibility of equipping VSU officers to provide EC to survivors of sexual violence. This intervention was directly informed by the findings that: 1) survivors were at risk of unwanted pregnancy due to the assault; 2) police were likely to see a victim within EC's window of opportunity; 3) EC could be safely provided by non-medical personnel, and is more effective the sooner it is taken.

Participants actively debated whether non-medical personnel could successfully be trained to distribute EC. The pilot was allowed to proceed based on two key precedents:

1. National family planning guidelines allow for employer and communitybased distribution of oral contraceptive pills, including EC; and

2. Zambian police have participated in employer-based contraceptive distribution programs.

Moreover, the notion of police personnel providing EC assistance to sexual assault survivors was in line with the reframed mission of the Zambia Police Service in its move toward emphasizing public service, in contrast to its prior focus as the Zambia Police Force on criminal law enforcement.

Recognizing that this pilot would require multi-sectoral oversight, collaboration and support, a steering committee was formed to guide implementation. The committee was chaired by the Provincial Health Director, who facilitated cooperation across the health, police and social service sectors. The Zambian Police Service assigned three officers to assist with the study. The Copperbelt Community Services Coordinator and the Copperbelt VSU Coordinator provided technical guidance to the study supervisor, and a provincial VSU officer oversaw police data collection. 


\section{The INTERVENTION}

The study was designed to strengthen the linkages between the police and health sectors through the provision of EC at the police stations, improving referrals across sectors, and increasing community awareness of both sets of services.

\section{Project sites}

Initial efforts included 20 urban and peri-urban police stations and rural police posts across three districts of the Copperbelt. In 2006, VSU officers and station management from these facilities were trained and equipped to provide $\mathrm{EC}$ as described below. In 2007, the number of sites was reduced due to difficulties in management and supervision. Transportation challenges associated with the loss of a dedicated vehicle forced the study to focus efforts only in the more accessible sites located in urban and peri-urban Ndola district. Between 2007 and 2008, the study operated in the five stations bolded in Table 3. All data presented in this report is drawn from these five stations.

\begin{tabular}{|c|c|c|}
\hline District & Study sites: 2006 & Study sites: $2007-2008$ \\
\hline Ndola & $\begin{array}{l}\text { Chifubu police station } \\
\text { Kasenshi police station } \\
\text { Ndola Central police station } \\
\text { Masala police station } \\
\text { Kafulafuta police station } \\
\text { Chipulukusu police post } \\
\text { Twapia police station } \\
\text { Sakania police station } \\
\text { Chambishi police station }\end{array}$ & $\begin{array}{l}\text { Chifubu police station } \\
\text { Kasenshi police station } \\
\text { Ndola Central police station } \\
\text { Masala police station } \\
\text { Kafulafuta police station }\end{array}$ \\
\hline Chingola & $\begin{array}{l}\text { Chingola Central police station } \\
\text { Garnetone police post } \\
\text { Kalulushi police post } \\
\text { Kitwe Central police station } \\
\text { Kitwe East police station } \\
\text { Mindolo police station } \\
\text { Riverside police station } \\
\text { Wusakile police station }\end{array}$ & \\
\hline Kitwe & $\begin{array}{l}\text { Chililabombwe police station } \\
\text { Chiwempala police station } \\
\text { Nchanga police station }\end{array}$ & \\
\hline
\end{tabular}


The 15 stations that were excluded from the study after 2006 requested that trained officers continue to provide EC to SV survivors. Under the direction of provincial and district authorities, district $\mathrm{RH}$ and VSU coordinators were given the opportunity to continue delivery of EC services in their facilities. No data was collected from these facilities after December 2006.

\section{Orientation of station managers}

At the outset of the study, one-day meetings were held to introduce the intervention to the district commanding officers and officers in-charge (OICs) of each station. Two meetings were held, one in Kitwe and one in Ndola, which brought together a total of 20 OICs from each district. As the senior officers at the participating stations, it was deemed necessary to secure their support and approval prior to implementation. The meeting worked to build consensus on the need to strengthen police response to SV by reviewing the formative research, highlighting the key elements of the intervention, and providing the OICs with a forum to discuss the issues associated with addressing SV within their stations.

In the course of study implementation, it was also determined that the buy-in of the shift supervisors was necessary for ensuring proper service provision. While the OICs serve as the overall leadership at each station, shift supervisors provide front-line management of cases and staff. Each shift has one supervisor who is responsible for ensuring that a VSU officer responds to all GBV complaints. On nights and weekends, when VSU officers are not on duty, the shift supervisor is expected to contact a VSU officer to respond to the case. To ensure that the shift supervisors were aware of the importance of contacting the VSU officer as soon as possible, and that they understood the benefits of EC provision for SV survivors, shift supervisors were also oriented to EC services under the project. In July 2005, a meeting was held to orient 20 shift supervisors (one from each station) on EC provision and their role in ensuring that all survivors receive the necessary services.

\section{Classroom training}

In February and March 2006, VSU officers from all 20 participating stations were trained to provide EC to SV survivors. Two classroom training sessions were held, one in Ndola and one in Kitwe, with a total of 36 officers participating in the course. At least one VSU officer from each selected station or post participated in the training, and larger stations sent two officers.

As directed by the study steering committee, VSU officers were trained under the MOH's Community-Based/Employer-Based Family Planning Distributor (CBD/ $\mathrm{EBD})$ curriculum to become employer-based distributors (EBD) of $\mathrm{EC}^{\text {viii }}$. The

\footnotetext{
viii Training was based on the Zambia Ministry of Health (MOH)/Central Board of Health
} 
training was conducted by the district reproductive health $(\mathrm{RH})$ coordinator, with technical assistance from the provincial VSU coordinator and the study supervisor. Training under this curriculum ensured that VSU officers met the accepted standard for distributing contraceptive methods, including EC.

The intensive 6-day program integrated an emphasis on EC, communication skills and sexual violence into the existing EBD training curriculum. Because most VSU officers had no previous formal exposure to reproductive health or family planning issues, the training ranged from the basics of anatomy and physiology to the specific health needs of SV survivors. The goals of the training were to provide VSU officers with knowledge and skills needed to deliver highquality EC services to survivors of rape and defilement, and to train them as EC EBDs in compliance with $\mathrm{MOH}$ standards. The training schedule is provided in Appendix 1 and Table 4 provides an overview of the training curriculum,

(CBOH) Training Manual for Employer-Based/Community-Based Distribution Agents (first draft, 1999).

\section{Table 4 Training curriculum}

\section{Lesson topics}

MOH

Lesson source

curriculum supplement

Background of population and development in Zambia

Introduction of the concept of EBD agents

Concepts and benefits of family planning

Male and female reproductive issues

Zambian family planning policies and methods

Prevention and management of HIVIAIDS and STIS

Prescribing and issuing EC and management of EC services

Quality of care issues in EC

Definition and social context of GBV and SV

Health and psychological implications of SV

Criminal aspects and laws relating to GBV

Rights of clients

Rumors and misconceptions

$\mathrm{x}$

Referrals for SV survivors

$x$

Counseling basics

$x$

Interpersonal communication skills, role plays

Clarification on policies and procedures for GBV survivors

Developing community awareness partnerships

$\mathrm{x}$

$x$

$x$

$x$

Study monitoring and recording

$x$

$x$

$x$

$\mathrm{X}$

$x$

Field visits to health facilities

$\mathrm{X}$


identifying which topics were augmented or refocused in light of the study's emphasis on GBV and EC. The effectiveness of the training was measured through pre and post tests, with final scores ranging between 85 and 100 percent.

One of the most challenging topics covered in the course was interpersonal communication. As police officers, the participants demonstrated an initial tendency to interrogate SGBV survivors as they would suspects. The role plays were very useful in encouraging the VSU officers to develop empathy with survivors and to conduct initial interviews in a less intimidating manner. In the course evaluation, participants affirmed the value of these role plays and suggested that future trainings include more of such sessions.

The training also benefitted from the multi-disciplinary facilitation team, which included health workers and police officers. Because of the regimented nature of police procedure, the presence of a high-ranking police officer throughout the entire course was necessary to demonstrate police commitment to the study and to resolve any questions about how the intervention accorded with institutional policy. The presence of experienced health professionals helped dispel misconceptions held by police officers relating to hospital policy, SV examination procedures, post-exposure prophylaxis for HIV and STIs, and answered basic questions on reproductive and sexual health.

\section{On-site training}

Not all VSU officers in the participating stations were released for the classroom training, and many stations anticipated and realized high personnel turnover rates. To ensure sustainability, during the study period and beyond, classroom training participants were also given training of trainers (TOT) instruction. Upon returning to their facilities, these trained officers were expected to provide on-thejob training to their colleagues. A health care provider, either from the provincial health office or study personnel, assisted the police with the trainings.

\begin{tabular}{|c|c|c|c|c|c|}
\hline District & $\begin{array}{c}\text { Police station/ } \\
\text { Post }\end{array}$ & $\begin{array}{l}\text { Number } \\
\text { trained in } \\
2005\end{array}$ & $\begin{array}{l}2005 \text { trainees } \\
\text { remaining at } \\
\text { site in Oct. } 08\end{array}$ & $\begin{array}{l}\text { Trained } \\
\text { on-site }\end{array}$ & $\begin{array}{l}\text { Total number of } \\
\text { trained providers } \\
\text { at site in Oct.08 }\end{array}$ \\
\hline \multirow{5}{*}{ Ndola } & Chifubu & 2 & 2 & 1 & 3 \\
\hline & Kansenshi & 2 & 1 & 1 & 2 \\
\hline & Ndola Central & 1 & 0 & 2 & 3 \\
\hline & Masala & 2 & 1 & 2 & 3 \\
\hline & Kafulafuta & 1 & 0 & 1 & 1 \\
\hline
\end{tabular}


Through a combination of both training modalities, each police station or post was able to retain at least one trained provider throughout the life of the project. This approach ensured the continuous provision of services despite high turnover, and provides the foundation for service sustainability after the study's conclusion.

\section{EC provision at police stations and posts}

At the conclusion of the classroom training, each station was given a set of basic supplies for providing EC to SV survivors. These included:

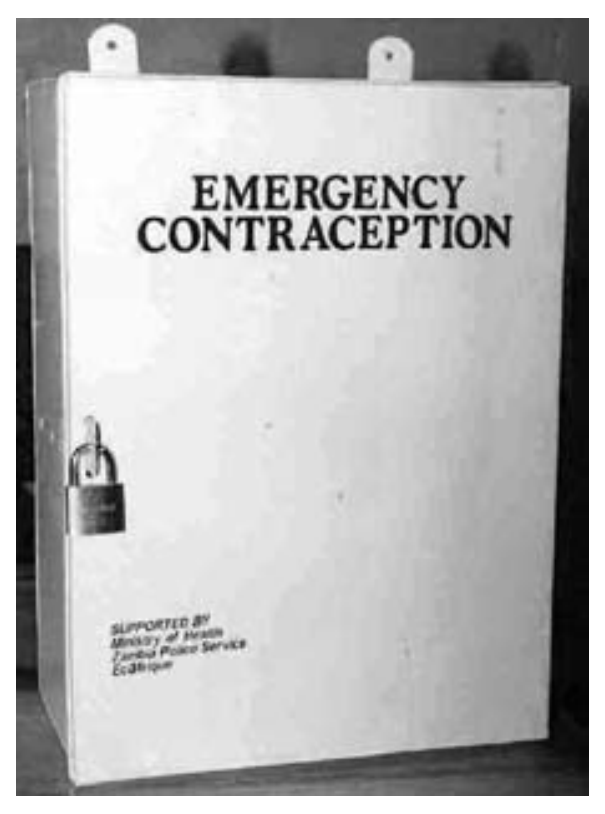

1. A secure, locked box for storing EC and the other supplies to ensure drug and record security. The metal box was to be permanently affixed on the wall of the VSU office (or other private room) at the police station, and the VSU OIC was given the key. In the course of implementation, it was recognized that the key needed to be accessible even when the VSU OIC was not in the station and access was extended to all trained VSU officers.

2. Provider aids. A client checklist was developed to assist providers in determining a survivor's eligibility for EC (see appendix 2). VSU officers were required to complete one checklist for each survivor seen and every dose of EC administered. Officers were also given a one-page synopsis of procedures for providing EC and referral services to SV survivors. This sheet was to be posted in the room where SV survivors are most commonly interviewed. Photocopies of the official Medical Report Form were also provided in order to ensure that all survivors were given the form free of charge.

3. Record-keeping tools. At the outset of the study, widespread concern was voiced that police officers would misuse the EC supplies. To guard against such misuse, stringent record-keeping procedures were put in place. VSU officers were required to account for every dose of EC distributed by providing a completed client checklist, entering it into a SV client logbook, and preparing a monthly report form. All of these forms were stored in the EC box, and in the case of discrepancies, could be checked for accuracy against the station's Occurrence Book. These forms were also used to collect service statistics for the study evaluation.

4. Stocks of EC and instructions for resupply. Each station was given an initial allotment of 20 doses of the dedicated EC pill Postinor-2. These drugs were provided by the $\mathrm{MOH}$ which was responsible for resupplying the stations out of a donation of 10,000 units by the Population Council provided to the $\mathrm{MOH}$ for use in this study. The district $\mathrm{RH}$ coordinator was charged with performing monthly supervisory visits to participating police stations. The mobile phone numbers of the district $\mathrm{RH}$ coordinator 
and the study supervisor were provided in the case of stock-outs or other technical assistance needs.

\section{Joint police-health sector supervision and coordination}

Supervision was designed to increase the linkages between the health and police sectors, and develop low-cost, sustainable procedures for scale-up. On a monthly basis, the district RH coordinator and VSU coordinator agreed to conduct joint supervisory visits. During these visits, they were to collect the monthly reporting forms, review the client checklists for accuracy and proper EC provision, meet with all trained VSU officers to discuss EC provision, other survivor needs, and record resupply requests.

In 2007, the district RH coordinator fell ill and could not perform these monitoring visits. For the remaining period, the study supervisor conducted these visits in conjunction with the VSU coordinator. As a qualified nurse midwife and family planning provider with close connections to the provincial health office, the supervisor was well-equipped to provide the necessary technical support. However, the intervention was ultimately unable to establish the feasibility and effectiveness of such joint supervisory efforts.

Ongoing coordination was fostered through regular "steering committee" meetings, which brought together VSU officers, health service providers and other stakeholders such as representatives from the Ministry of Community Development and Social Services, the YWCA, Catholic Diocese, and participating communities. These meetings rotated between the hospital or district police offices, and were chaired by senior staff at the hosting institution. Discussions enabled continuing communication between all stakeholders and encouraged a sense of teamwork. Issues arising from these meetings were addressed at yearly meetings of senior health and police staff, which discussed emerging policy and procedural issues that needed high-level intervention.

\section{Community outreach}

Another component of the overall intervention was that the trained VSU officers would conduct periodic community outreach in their areas to sensitize their community on GBV, EC, and the new intervention. As part of the initial training course, VSU officers developed community outreach plans to augment the community outreach activities undertaken as part of their regular duties. These plans included outreach to the participating communities, including schools, on topics and procedures regarding sexual and gender-based violence. 


\section{Strengthening the health sector}

While the intervention focused primarily on strengthening police responses to SV, it also recognized the need to improve health care at referral facilitates. To do this, it provided training on EC and GBV to 23 doctors and nurses from the 17 health facilities that were included in the formative research.

As the study progressed, efforts to strengthen the health sector focused on the two referral hospitals in Ndola district: Ndola Central and Arthur Davidson Children's Hospital. With support from the study steering committee, the study supervisor worked with the facilities to establish policies and procedures for responding to SV cases, and to develop stronger linkages with the police.

To overcome barriers to access associated with cost, Ndola Central Hospital posted a sign clearly stating the policy that no fees would be charged to provide services to SV survivors. The Hospital and study staff worked to ensure that the hospital cashiers and nurse-in-charge of the casualty department (the entry point into hospital) were aware that no fees should be assessed in SV cases. Staff in the casualty department were also oriented on the basic elements of clinical management of SV.

Officers serving in the police post located in Ndola Central Hospital were also oriented on SV responses, although they were not selected to participate in the study because of their location within the hospital. The study coordinator worked with the police post to establish expedited procedures for SV survivors.

Trained VSU officers also encouraged hospital staff to quickly inform police when Medical Report Forms had been completed so that they could be collected as evidence. This aspect of the intervention was reported to reduce the lag time in Form collection from weeks to an average of three days. 


\section{Evaluation Methodology}

The study included both qualitative and quantitative outcome measures. Data collection for the final evaluation took place in October and November 2008.

\section{Service statistics from police stations}

Throughout the study period, service statistics were regularly collected on a monthly basis from the police stations listed in Table 3. The monthly reporting form was designed to correspond with the monthly log form used by the $\mathrm{MOH}$ at the provincial level, to help make the form more accessible to the district $\mathrm{RH}$ coordinator who was initially charged with collecting and compiling the data.

The form collected information on all SV survivors who were seen by VSU officers. It recorded the following data: number and age of survivors; number of EC doses administered, reasons for not administering EC if eligible, and referrals to health facilities. Data from January 2006 to December 2008 was included in the analysis.

\section{Provider KAP survey}

As part of a related activity, the project conducted a knowledge, attitudes and practice (KAP) survey among police, health care providers and counselors in Ndola and Kitwe districts. A total of 210 police officers were interviewed from 15 police stations and posts across the Province. Five of these facilities were the intervention sites outlined in Table 3, seven were included in the study in 2006 but dropped out in 2007, and the remaining three were never exposed to the intervention. Of the original 36 VSU officers trained under the study, 15 were captured by the survey. This underscores the high levels of staff turnover experienced within the Police Service.

At these sites, 100 percent of the police officers who regularly come into contact with a SV survivor were surveyed, including VSU officers, OICs, shift supervisors, and inquiry desk officers. This survey was conducted in September 2007, a year before the final evaluation took place.

\section{Focus group discussions and in-depth interviews}

In November 2008, qualitative data on the program's impact was gathered through a series of focus group discussions (FGDs) and key informant interviews (KIIs). The objective was to assess successes and challenges in the project performance and compare them with the experiences reported by the comparison area. As outlined in Table 6, respondents included all cadres of police and members of the communities associated with the stations. 


\begin{tabular}{|c|c|c|}
\hline $\begin{array}{l}\text { Respondent } \\
\text { type }\end{array}$ & $\begin{array}{l}\text { KIls and FGDs conducted in } \\
\text { intervention sites }\end{array}$ & $\begin{array}{l}\text { KIIs and FGDs conducted in } \\
\text { comparison sites }\end{array}$ \\
\hline Police officers & $\begin{array}{l}1 \text { FGD: classroom trained VSU officers } \\
1 \text { FGD: Peer-trained VSU officers } \\
1 \text { FGD: CID officers } \\
1 \text { FGD: Station officers-in-charge } \\
\text { KII: District commanding officer } \\
\text { KII: Hospital police officer }\end{array}$ & $\begin{array}{l}1 \text { FGD: CID officers } \\
1 \text { FGD : shift officers } \\
1 \text { FGD: Station officers-in-charge }\end{array}$ \\
\hline Medical sector & $\begin{array}{l}\text { KII: Head of obstetrics and gynecology } \\
\text { KII: Sister-in-charge of obstetrics and } \\
\text { gynecology } \\
\text { KII: Sister-in-charge of ART clinic } \\
\text { KII: Provincial health official }\end{array}$ & \\
\hline $\begin{array}{l}\text { Community } \\
\text { members }\end{array}$ & $\begin{array}{l}3 \text { community FGDs: Masala, Kafulafuta, } \\
\text { Chifubu }\end{array}$ & \\
\hline
\end{tabular}

All five intervention sites were included in this data collection exercise, and two sites that were never exposed to the intervention were included for comparison. The comparison site was Luanshya police station, where several focus group discussions with police officers at different ranks were conducted. Luanshya is a neighboring district with police stations that are similar to Ndola. Criteria for selection of the comparison site included: 1) no previous interaction with the program or police trained under the program; and 2) similar facility characteristics, such as size, staff composition, and catchment area population. It was not possible to conduct discussions with health care providers or the community in the comparison area. 


\section{Results: Service Statistics}

\section{Police effectively provided EC}

Over the life of the intervention, VSU officers in all 20 stations provided a total of 357 doses of EC to survivors of sexual violence. Of these, 195 (55 percent) were provided by the five stations that participated in the intervention for all three years.

No adverse events or complaints were reported in any of these cases. Client checklists demonstrated that all doses were provided to women or girls within reproductive age, and EC was never given to girls younger than 10 years of age. In 2006 and 2007, two stations provided five doses to non-sexual assault clients who were referred by a neighboring health facility that was experiencing a stock-out of EC. While such inter-sectoral collaboration is admirable, these referrals were discontinued in order to ensure that police only provided EC to sexual assault survivors in response to stakeholder concerns over broader police provision.

These data demonstrate that police can safely and effectively provide EC to survivors of SV.

\section{Reporting to police increased}

The study tested the hypothesis that police provision of EC, and the service improvements that accompanied it, would increase the number of survivors who sought police support. From 2006 to 2007, reporting increased by 48 percent, suggesting that the intervention did encourage survivors to present to the police station. From 2007 to 2008, however, reports decreased by 24 percent (Table 7).

\begin{tabular}{|lccccccc|}
\hline Table $\mathbf{7}$ & \multicolumn{6}{c}{ Total number of SV cases reported to VSU officers, 2006-2008 } \\
\hline & $\begin{array}{c}\text { Ndola } \\
\text { Central }\end{array}$ & Masala & Kanshenshi & Chifubu & Kafulafuta & TOTAL & $\begin{array}{c}\% \\
\text { increase }\end{array}$ \\
\hline 2006 & 108 & 22 & 12 & 16 & 12 & 170 & \\
2007 & 160 & 38 & 26 & 20 & 7 & 251 & 48 \\
2008 & 103 & 42 & 23 & 20 & 3 & 191 & -24 \\
\hline TOTAL & $\mathbf{3 7 1}$ & $\mathbf{1 0 2}$ & $\mathbf{6 1}$ & $\mathbf{5 6}$ & $\mathbf{2 2}$ & $\mathbf{6 1 2}$ & \\
\hline
\end{tabular}

The decline in reports from 2007 to 2008 is most likely associated with the unexpected death of President Levy Mwanawasa in August 2008 and the subsequent presidential elections held in October 2008. These events disrupted 
public sector services in general, and placed additional requirements on the police service to conduct special duties related to the President's death and the elections. Because the data below reflects only SV cases reported to VSU officers, it is likely that the absence of these specialized officers from their duty stations accounts for the lower number of cases recorded in 2008. It is also likely that a significant number of survivors who reported to the police during this period were attended to by general police officers who did not have specialized training in GBV.

\section{The majority of survivors reporting to the police were adolescents}

Of the 612 survivors who reported to the police facilities in the study, 49 percent were under the age of 14 and 85 percent were under 19. As demonstrated in Figure 1, the age distribution was similar across the three years of the intervention and was consistent with the formative research conducted at the outset of the study. This suggests that the survivors presenting during the study period were representative of general reporting patterns.

\section{Figure 1 Age distribution of survivors reporting during formative research and intervention years}

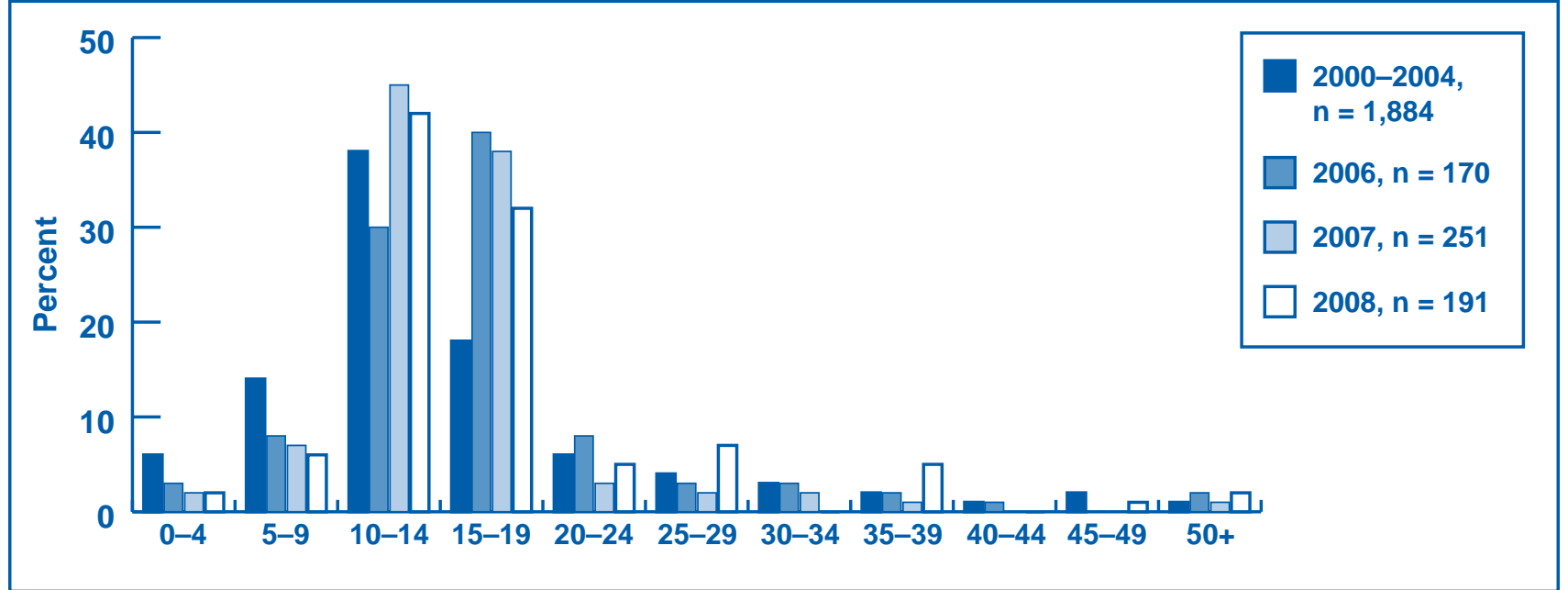

It is important to note that this age distribution includes only survivors who report to the police, and does not reflect the prevalence of sexual violence in the general population. It is likely that cases involving adult women are significantly underreported. 


\section{Access to EC improved, but remained inconsistent across stations}

Overall, 41 percent of eligible survivors received EC. For the purposes of this analysis, an eligible individual is one who reported to the police station following SV, reported within 72 hours of the assault and was 10 years or older. Of the 612 cases that reported, 442 met these criteria.

As Table 8 highlights, access to EC varied considerably across stations and time. This is most likely due to the attrition of VSU officers trained under the study. In the first full year of the study, all participating stations realized provision rates of at least 50 percent. Turnover of trained providers affected the majority of the stations in the second year, and provision rates subsequently declined. Although the departing VSU officers were expected to train their colleagues before leaving, the performance of the peer-trained providers was notably worse than that of their classroom-trained colleagues. Realizing the impact of staff attrition on EC access, the study coordinator provided intensive on-site training to the new officers in 2008.

\begin{tabular}{|lccccc|}
\hline Table 8 Percent of eligible survivors receiving EC, by station and year; $\mathbf{n}=\mathbf{4 4 2}$ \\
Station & 2006 & 2007 & $\mathbf{2 0 0 8}$ & Average \\
Kafulafuta & $\%$ & $\%$ & $\%$ & $\mathbf{6 7}$ \\
Chifubu & $\mathbf{7 1}$ & $\mathbf{8 0}$ & 33 & $\mathbf{5 9}$ \\
Ndola Central & $\mathbf{6 7}$ & $\mathbf{6 0}$ & $\mathbf{5 5}$ & 41 \\
Kanshenshi & $\mathbf{5 1}$ & 22 & $\mathbf{6 3}$ & 41 \\
Masala & $\mathbf{5 0}$ & 25 & 42 & 35 \\
Average & $\mathbf{5 0}$ & 35 & 15 & 31 \\
\hline
\end{tabular}

*Provision rates above $50 \%$ are in bold.

The impact of trained staff is most clearly illustrated in Chifubu Police Station. This station maintained two classroom-trained VSU officers throughout the life of the study, and was also the only station to consistently provide more than 50 percent of eligible survivors with EC. Both Kanshenshi and Masala stations retained one classroom-trained officer each, but these officers were out of the station for long periods on leave or special duties. As a result, their provision rates were lowest in the years when these officers were not available. The experiences of these stations demonstrate the importance of maintaining well-trained VSU officers in order to ensure the greatest possible access to EC. 


\section{High referral rates}

Formative research demonstrated that 91 percent of survivors reported to the police before presenting at the health facility. Service statistics confirmed this finding, with 94 percent of survivors indicating they did not visit a health facility prior to seeking police assistance. To ensure that survivors receive comprehensive SV care, including medical services and forensic evidence collection, the study emphasized referrals to neighboring hospitals as an important part of SV service provision.

The data given in Table 9 demonstrate that the level of referrals was uniformly high across the intervention sites, with the notable exception of Ndola Central Police Station. Other program data suggest that the rates reported at Ndola Central are likely to be inaccurate, possibly due to misinterpretation of the field on the reporting form. For the purposes of this study, referrals were defined either as the provision of information on services available at the hospital or physically accompanying the survivor to the health facility.

\begin{tabular}{llcccc} 
Table 9 Percent of all survivors referred to health facility, by station and year; \\
$\qquad \begin{array}{l}n=612 \\
\text { Station }\end{array}$ & 2006 & 2007 & 2008 & Average \\
Chifubu & $\%$ & $\%$ & $\%$ & $\%$ \\
Kanshenshi & 100 & 100 & 100 & 100 \\
Masala & 100 & 100 & 100 & 100 \\
Kafulafuta & 77 & 100 & 100 & 95 \\
Ndola Central & 92 & 86 & 0 & 77 \\
\hline
\end{tabular}

*Referral rates above $95 \%$ are in bold.

As with EC provision rates, the most consistently high-performing station was Chifubu, which benefitted from presence of a classroom-trained VSU officer throughout the study. Both Kanshenshi and Masala also retained a classroomtrained officer throughout the study, although they were on leave from the station for long periods of time. In the absence of pre-intervention data, the impact of the intervention on these sites cannot be accurately assessed. Nonetheless, the majority of VSU officers at these sites demonstrated the willingness and ability to refer survivors for medical care. 


\section{Results: Provider KAP survey}

The provider KAP survey, conducted in 2007, provides insight into the police's capacity to deliver the services discussed above. Because it was conducted at the mid-point of the evaluation, it primarily reflects the impact of the orientation and classroom training activities.

A total of 210 police participated in the survey, with 25 respondents indicating that they received some form of training during the study period. Of these trained police, 15 were VSU officers who participated in the intensive 6-day classroom training (Table 10). The other 10 participated in the 1-day orientation course for station management.

\begin{tabular}{|lccc|}
\hline Table $\mathbf{1 0}$ Sample characteristics & & \\
\hline & All respondents & Participated in study & $\begin{array}{c}\text { VSU officers trained in } \\
\text { classroom under study }\end{array}$ \\
$\mathrm{N}=$ & 210 & 25 & 15 \\
$\%$ female & $33 \%$ & $32 \%$ & $40 \%$ \\
Mean age & 35 & 36 & 33 \\
\hline
\end{tabular}

Data indicate that officers trained under the study consistently demonstrated higher knowledge levels on EC and more frequently referred survivors for health, legal and psychosocial care. As Figure 2 demonstrates, trained officers

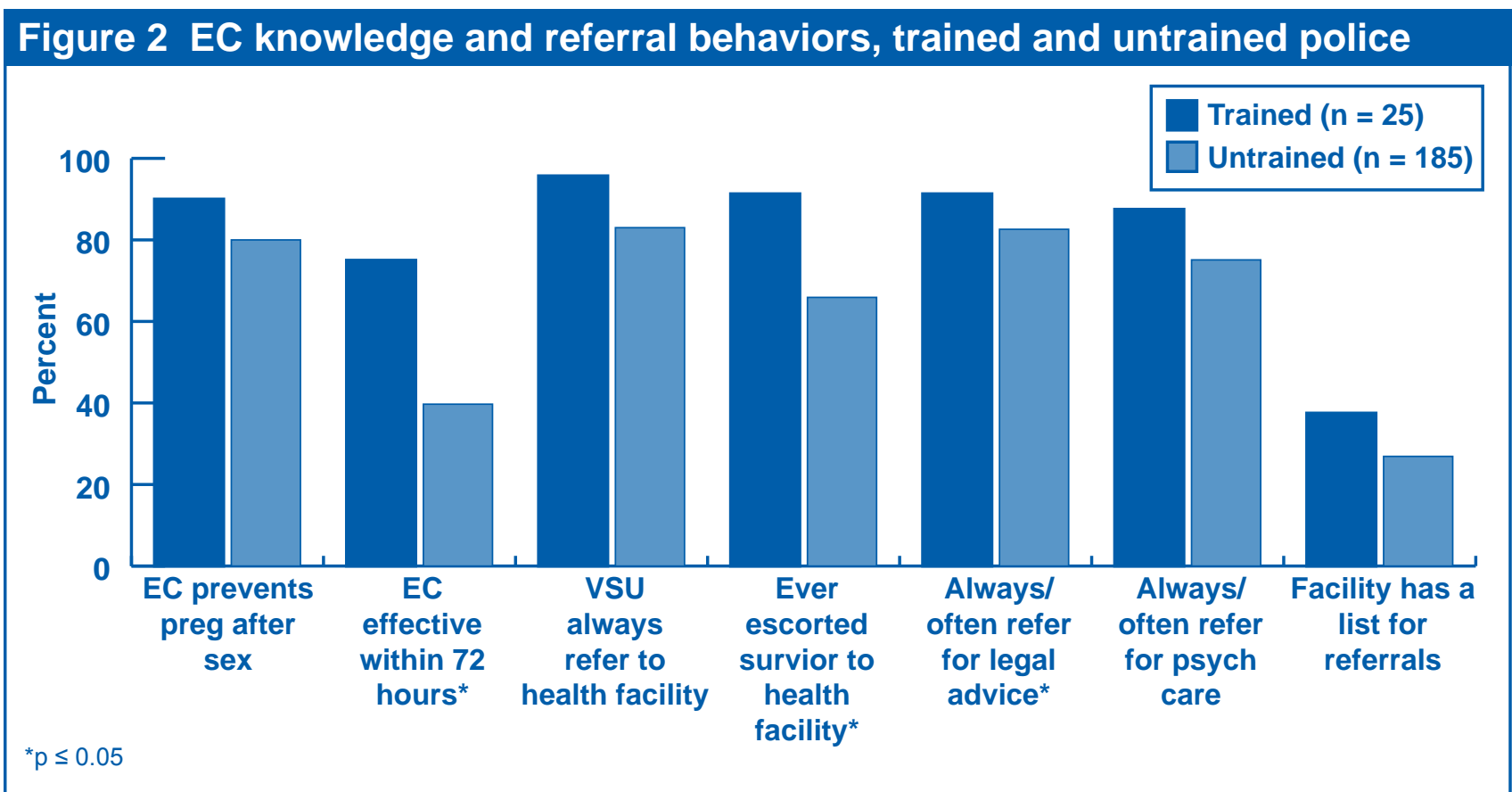


were significantly more likely to know EC's window of effectiveness, personally escort survivors to the health facility, and refer them for legal advice and support. Knowledge of EC was even higher among the trained VSU officers, 100 percent of whom knew that EC prevented pregnancy after unprotected sex.

While knowledge and practice appears to have improved in the intervention's core areas, results were less conclusive in regard to medico-legal evidence collection (Figure 3). Trained VSU officers were less likely to agree that the health facility staff and police always worked well together in rape and defilement cases, and were significantly more likely to incorrectly agree that police officers must physically examine a survivor in order to legally determine if a sexual assault has occurred. These responses may reflect attitudinal changes that accompanied the in-depth training, potentially giving police greater (but unfounded) confidence in their skills to assess sexual assault and increasing their expectations of health care providers.

\section{Figure 3 Perceptions of trained and untrained police about medico-legal issues}

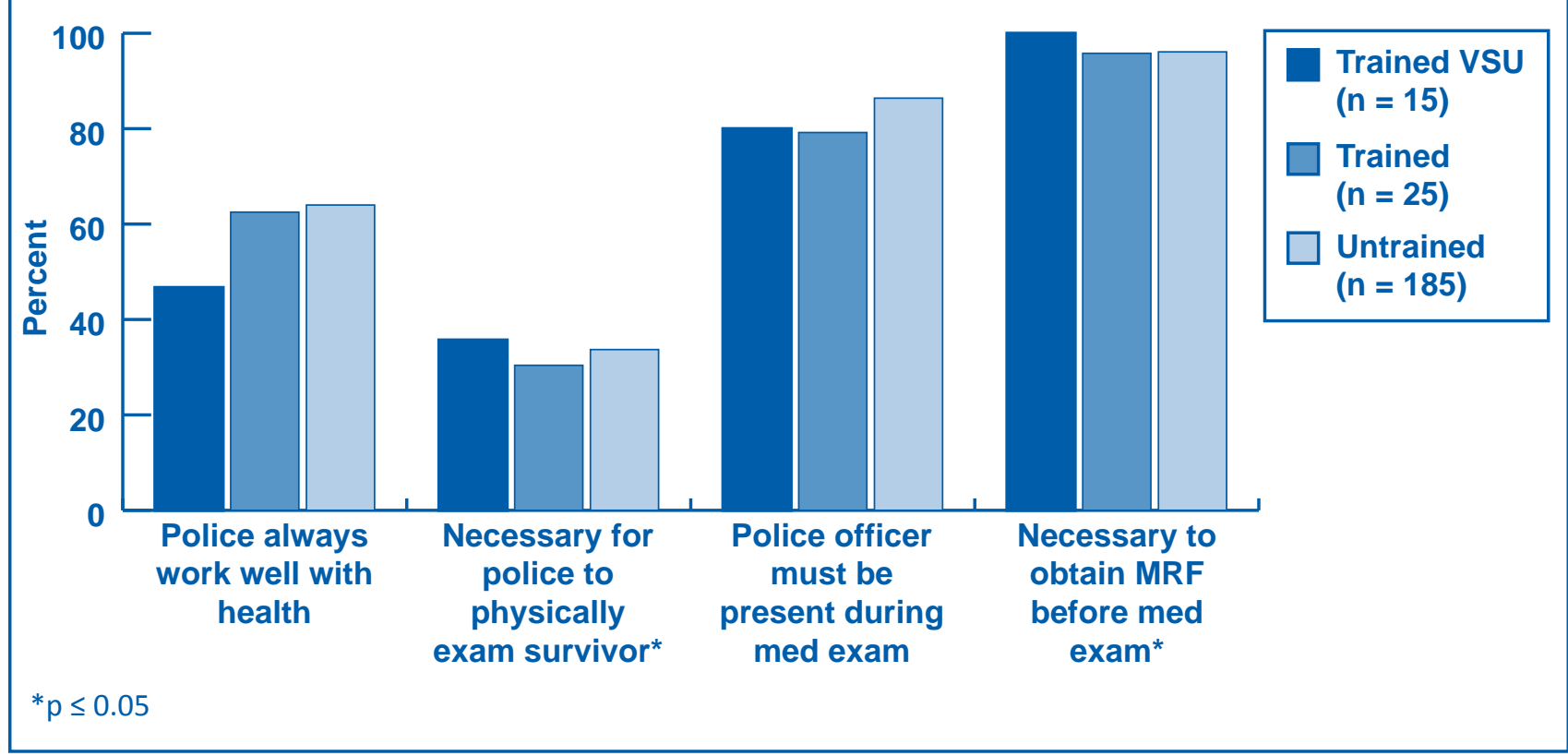

Trained officers, however, were slightly less likely to agree with the incorrect statement that a "police officer must be present during the medical examination of a rape and defilement survivor," which also may reflect greater confidence in health care providers. Significant increases were seen in trained providers' attention to ensuring proper documentation, with 100 percent of all trained VSU officers stating that it is necessary to obtain a Medical Report Form (MRF) prior to conducting a forensic examination. 
As indicated by the formative research, illegitimate fees associated with health and police response were identified as a barrier to seeking care. The study addressed this by providing free MRFs to participating stations and addressing the issues in the training. These interventions appear to have had a positive impact on providers' knowledge of the costs associated with post-rape and defilement services. While only 53 percent of untrained providers were aware of the $\mathrm{MOH}$ policy to provide free medical care to sexual violence survivors, 73 percent of trained VSU officers knew such treatment was free. Not one trained officer indicated that there were any fees associated with obtaining an MRF.

Fewer trained VSU officers, however, indicated that all police services were free. Significantly more trained officers noted that a survivor must bear the cost of a police officer's transport to the health facility (Figure 4). Although this proportion is relatively low, it does suggest that the intervention may have increased the perception among police that survivors must pay for police services. It is possible that this represents a reaction to the intervention's emphasis on increased referrals to the health facility.

\section{Figure 4 Service costs, perceptions of trained and untrained police}

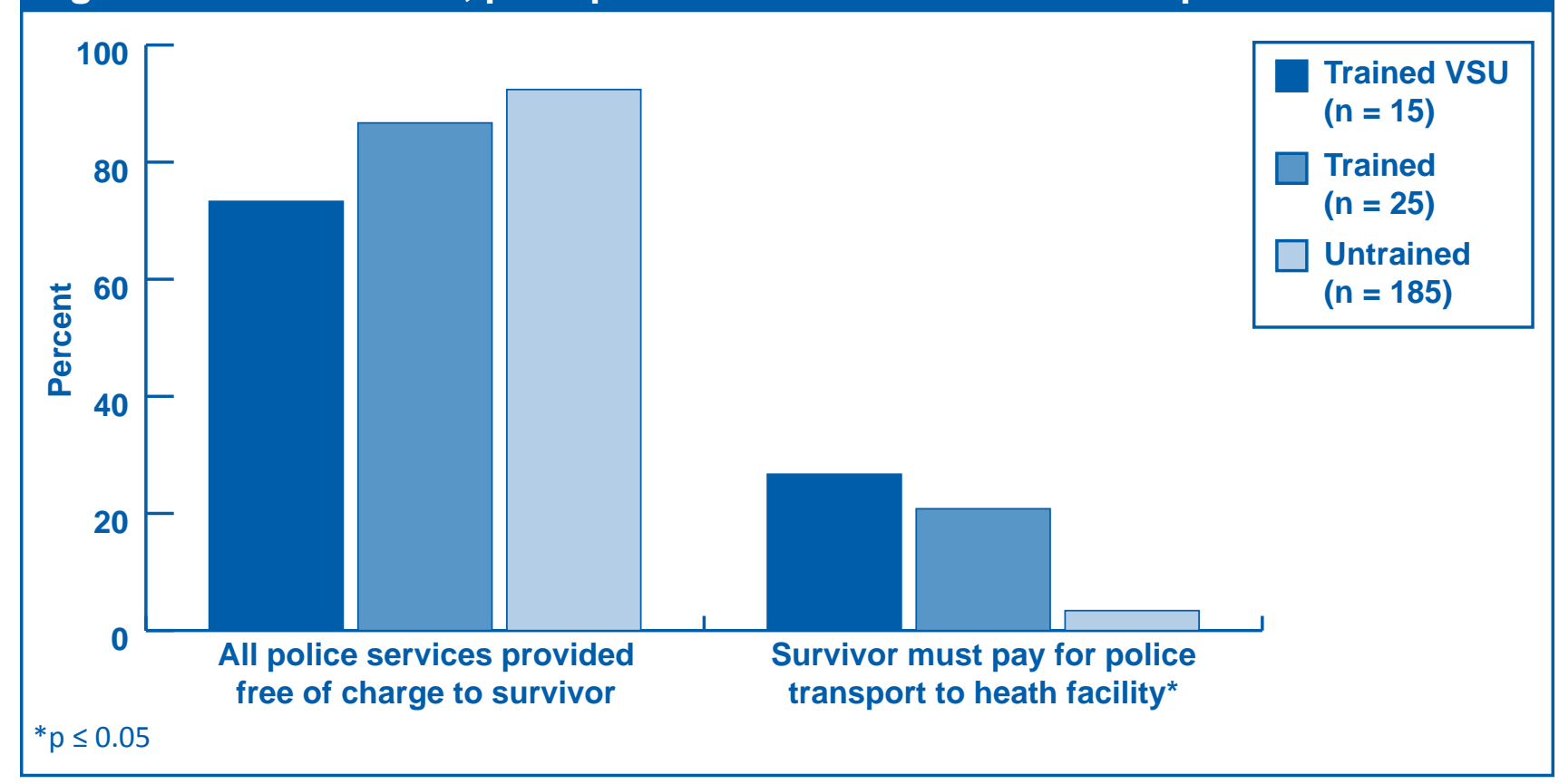




\section{ResULTS: KIls AND FGDs}

At the conclusion of the intervention, qualitative research was conducted to assess perceptions of program impact.

\section{Health personnel reported no problems with police officers dispensing EC}

At the outset of the study, health care providers expressed concern over the police's ability to provide EC. The final evaluation indicated that health facility personnel experienced no difficulties or problems associated with the intervention. No adverse events had come to their attention, and hospital management noted: "we have not had any problems. When [the police] give EC, they advise victims to come to hospitals and we would have picked up if any problems happened and retrained them."

According to senior hospital staff, "we haven't faced any challenges regarding these EC being administered by police officers. If any, it has made our job easy because by the time survivors come to the hospital, they already have received some help so we just pick up from where our friends ended."

\section{Linkages between the health and police improved}

Interviews with both police and health facility personnel demonstrated an improved cooperative working relationship between the two sectors.

An important element of the study design was forging links between the intervention sites and local hospitals and health centers. Thus, the officers were confident about being able to refer problems to health facilities for follow-up. According to a trained VSU officer, "When a victim who has received EC develops reactions or complications, we can assist because currently we have a strong link with the gynecology ward at Ndola Central Hospital which has the capacity and expertise

“We haven't

faced any

challenges

regarding

these EC being

administered by police officers."

-Hospital staff to look at such cases". Although no reactions or complications were reported, the police consistently demonstrated correct knowledge of referral procedures for such cases.

Officers described a more efficient process for communication between the police and health sectors. Previously, there had been a lack of awareness and gaps in communication between these sectors, as health facilities had focused more on patient care and gave lower priority to forensic evidence collection or timely completion of the Medical Report Form. After the project inception, with the new levels of cooperation between the sectors, these procedures were more efficiently followed. 
Improved SV services within the health facility were also attributed to the study interventions. According to provincial-level health management, "due to the effect of the [EC] program the health care providers are more responsive to $S G B V$ victims unlike in the past, which is a good improvement. At the moment $S G B V$ are treated as emergencies due to the 72 hours window period. "Similarly, VSU officers noted that "doctors at the hospital attend to clients and have been sensitized... First they start from casualty, but when it comes to GBV cases we skip the line and go to the gynae ward."

However, challenges remained within the health facilities, especially in regard to documentation and forensic evidence collection. According to senior staff at Ndola Central Hospital, "we are a training hospital. Some doctors are on rotation and may do the wrong thing... evidence may not be gathered... we have a high turnover of doctors. ... Fortunately we have good relations with the police... we interact...very well." VSU officers also observed obstacles: "usually we follow up the cases at the hospitals but mostly they take long to come up with the report because not every doctor has been given the mandate to sign on these reports.... Forms take long to get signed... after three to four days we go back to hospital to see if they are signed."

\section{Police consistently refer survivors for health care}

Confirming the findings of the service statistics and the provider KAP, qualitative interviews with police officers demonstrated high levels of awareness regarding the need to refer survivors to appropriate services. In both the intervention and comparison sites, officers correctly identified the need and process of referring a survivor to the health facility.

Trained officers demonstrated higher knowledge of EC and the services available at the hospital. Every trained officer interviewed reported discussing EC with eligible survivors, and reported referring survivors to health facilities for medical care and medico-legal evidence collection. As one trained VSU officer observed: "these clients need EC, they also need referral to the hospital for further tests. They also need PEP to prevent HIV... follow-ups to monitor victims' PEP intake... psychosocial counseling."

Officers in the comparison sites also reported consistently referring survivors to health services, although their relationship to health care facilities and providers was not as cooperative as those in project areas, and service fees were often charged by area health facilities.

In addition to health care, officers in all sites expressed that survivors needed psychosocial support, including immediate and ongoing counseling and services tailored for children and minors and noted that appropriately trained counselors were lacking. Most officers in both intervention and comparison sites reported that police stations maintained a network of counseling services offered by faithbased groups, community organizations, or non-governmental organizations, in
"Due to the effect of the [EC] program the health care providers are more responsive to SGBV victims." manager 
addition to services available in hospitals. Survivors were referred to these facilities based on their geographic location, need, or other factors. However, referrals were hampered by the general lack of trained counselors, and the need for survivors to move from venue to venue to access services. According to an OIC of an intervention site "a survivor needs a safer place... survivors needs counseling...they need a place where police officers can be found and psychosocial service offered there and then." Such services, it was noted, do not currently exist.

\section{Lack of transportation undermines police's ability to refer}

While awareness of the need to refer was high, transportation costs were consistently identified as a barrier to seeking further services. The KAP survey highlighted barriers associated with transportation, with trained officers significantly more likely to believe that the survivor must pay for such services. The qualitative research adds further perspective to this finding, and identifies the lack of dedicated police vehicles as a key factor undermining referrals, follow-ups and the police's ability to investigate crime scenes.

All police facilities in the study, especially those in rural areas, reported difficulties with transportation. Where police vehicles were available, they were often not roadworthy or were engaged in other activities when GBV survivors needed to be transported. Officers reported scrambling to find private or donated transportation to take assault survivors to hospitals, sometimes paying from their own pockets. One CID officer said: "distance also...going to the hospital it is very far, so we have a transport problem... or for example at Chifubu Police Station we have one vehicle which does all station activities which need transport so we can't rely on it, so in some fortunate cases we ask the paralegals or community for assistance in that area for transport."

"The biggest hurdle we are facing is the lack of transport because in most cases when a victim comes with a Police officer, it is the victim who pays for all transport costs."

-Hospital nurse
Health personnel also reported that because of time and transportation problems, many survivors (especially minors who have to be escorted by adults) do not return to the health facility for follow-up visits and counseling services. A nurse at Arthur Davidson Hospital said: "but the biggest hurtle we are facing is the lack of transport because in most cases when a victim comes with a police officer, it is the victim who pays for all transport costs."

Community members also reported that the difficulties and expenses of finding transportation (when none was available at police stations) posed a considerable challenge in adhering to referral and follow-up schedules. In Chifubu, a respondent noted that police face a "lack of transport to get to the scene, usually the police complain of transport when you call them to come to the scene."

In Kafulafuta, a community member observed "we lack transport to get to town to the hospital;" and another VSU officer observed that "we are in rural areas which have cases from very remote places. We need transport to reach emergency help from remote areas." 


\section{Survivor intake procedures improved at police facilities}

Throughout training and supervision, study staff emphasized the need to respond quickly and confidentially to a survivor's needs. FGDs conducted with trained officers at the study's conclusion indicated that in all participating police stations, intake procedures for sexual assault survivors had been amended to reflect greater appropriateness and sensitivity to the survivor. In all study sites, officers reported that as a result of the intervention, survivors were no longer required to wait in line with other clients. They are now attended to immediately; as soon as they make it known that they have come to register a case of sexual violence.

The process, as described by one project-trained officer, entails: "firstly, we welcome them [the survivors], we counsel them about what to expect, about possible treatment, tests, results and what has to follow. We then open a record, if eligible for EC we give it to that client, and educate them about EC and other available services at the police and hospital..., we refer them and escort them to the hospital. We take keen interest in the results of the examinations that take place at the lab. We then wait for the results right there at the hospital. The doctor signs a Medical Report Form and finally, we arrest the perpetrator." This procedure was described in almost identical terms by another set of FGD participants, adding that "we reassure the survivors".

\section{Fees for GBV cases eliminated in hospitals associated with the intervention}

As noted above, the police KAP survey demonstrated that 74 percent of trained VSU officers were aware that all health services should be provided to survivors free of charge. By the study's conclusion police officers in intervention sites were unanimous in reporting that no fees were charged to survivors for any associated procedure, test, or investigation at health facilities.

Interviews with senior staff at the two hospitals associated with the study also confirmed that no fees were charged to SV survivors who presented with a Medical Report Form. The officials also noted that although this policy was national, due to lack of awareness, it frequently was not implemented in other facilities.

This change was attributed to the leadership of the project "steering committee." According to the project manager, "the office of the Provincial Health Director was useful to have as the chair of the steering committees as he was the chair of overall health services. It was useful to have him communicate with other health directors, so that for Ndola, the service charge has been waived for SV survivors as long as they present with that complaint at the reception. In [another district] some people were being charged, but in Ndola Central, for the sake of privacy they were presenting themselves as being beaten (and revealed SV only later). So the steering committee brainstormed and sought solutions. "The result was that in hospitals associated 
"Now we quickly report to the police because we know we will find assistance like EC." member with the study, the policy on not charging fees to SV survivors was consistently implemented.

In contrast, police officers in the comparison sites reported that personnel in hospitals in their area often charged fees for completing and signing forms (reportedly as high as 40,000 Kwacha or 10 USD), which posed a significant financial burden for survivors and their families. Often, these officers reported having to intervene and request that the fees be lowered or waived. As one CID officer noted, "the hospital charges for the medical report form to be signed by the doctor ... If the survivor goes alone, they are charged." Another officer recounted, "one victim I took to the hospital was charged, then it also takes a very long time to get results...but in most cases relatives of the victim foot the bill".

\section{Communities more comfortable reporting to the police}

Overall, community members from target communities reported a high degree of satisfaction with the outreach activities conducted by VSU officers under the study. Interviews with members of these communities indicated that they had had a high degree of awareness about correct policies and procedures relating to reporting cases of sexual violence to the police and the hospital, including knowledge of the correct time frame for EC and PEP for HIV. This awareness and increased comfort with the police and, they contend, has increased a survivor's willingness to report.

In the words of one community member from Chifubu, "most community members are well informed about these issues these days, so their reporting habits have improved tremendously. "Another respondent from the same community agreed that "far back we were ignorant and just used to stay home when such a thing happened to you, but now we quickly report to the police because we know we will find assistance like EC etc." As a result, according to a community member from Masala, "in the past, families used to settle defilement and rape cases just within the family, but now things have changed, like recently a father who defiled his daughter has just been jailed."

Trained VSU officers felt that the project had enhanced their ability to serve their populations. One officer noted, "this program has broken barriers. Now we work with stakeholders ... the community is free to come to the police." Another officer noted that "the EC program has helped us work well and do our work better... It has also helped us to have improved relationships between police, $\mathrm{MOH}$ and other stakeholders... and the community because we are being seen to care for their lives, they see us as friends now... it has created partnership with Paralegal, YWCA, MOH and it's institutions, and other stakeholders and NGOs."

Health care providers also noted that as a result of the intervention, the public was more aware of the importance of seeking timely medical attention in cases of sexual assault, and were more inclined to do so. A provincial health official 
commented "now there is more sensitization. Many people are reporting because of this EC program." Senior staff at Ndola Central Hospital also said "we have more and more people coming in. Earlier they used to be charged to get the police report, and had transport problems. Now people are coming almost immediately."

Nonetheless, it was widely agreed that GBV cases are significantly underreported in all communities. Perspectives from community members in Chifubu added to the picture: "These cases have always been many, it is just that a lot of people kept them as secrets. ... We have about 15 to 20 cases per month. ... And the rest of the cases are unreported, we don't know about them."

Reasons for not reporting cases included that many assaults were perpetrated by family members, so that survivors' families were reluctant to cause scandals or have a breadwinner prosecuted and jailed. In other cases, families settled the matter among themselves usually by exchanging money.

\section{Gaps remain in social services, especially for children}

While the intervention improved the quality of services in the police and health sectors, all respondents noted that gaps existed in terms of psychosocial care and services for child survivors.

Trained police officers noted difficulties involved in the intake of a case where a very young child was a survivor: "We need a lot of training on how to deal with children, because the court requires that we present a statement from the victim but in case of a kid it's very diffcult to extract information especially those who are five years and below."

Police officers and health providers expressed reluctance to return children back into potentially unsafe home environments, and have pointed out the need to establish a network of safe houses, shelters, and similar services for minors. A few faith-based organizations had begun to offer such facilities on a very limited scale. A member of Chifubu community said "organizations like Isubilo helps those kids connected to it, it helps them find safe places, and we also communicate with social welfare." Another member of the community noted "depending on the situation, a safe place for the situation is needed, in case the perpetrator is from the household" and another replied "it is a good idea, but where do we take them?"

Health facility personnel also confirmed the importance of immediate and ongoing counseling services, especially for children, but noted that trained staff were lacking (especially those with pediatric expertise). A health professional who handled cases daily said "I want to be equipped with child counseling skills." This was echoed by another senior hospital staff member, "child counseling skills are really needed for providers at police and health institutions." 


\section{Project perceived as sustainable and replicable}

According to a provincial health official, "this program is sustainable because it has become institutionalized. It has become part of what people do in their jobs, in hospitals and also with police. As long as the Ministry of Health puts it in their plans, and the Memorandum of Understanding between the Ministry of Health and Ministry of Home Affairs continues. Everybody has been very cooperative with this plan to succeed. We have shown it works. We need to support scale up to all areas."

A senior police official also noted that human resources are critical to maintaining the intervention. "It can be sustained if the trained police officers are available... we need manpower in the police, hospitals, and other stakeholders...experts to give opinions in court are limited."

In terms of financial resources, a provincial health official noted that "this program is resource cheap in the sense that it doesn't need a lot of funds to be sustained; keeping in mind that the most expensive part of sustainability of such programs is manpower which we partly have in an already existing system. The program's demands are also within what we have in place: labs, PEP, a reproductive health department which provides EC. We have doctors who attend to these cases. Hence, this program should be scaled up...nationwide... because there's a lot of cooperation amongst health institutions, police and other stakeholders."

The study manger also observed that "all stakeholders appear keen to continue and scale up the project. The Ministry of Health said 'don't leave a good program stagnating, let us not wait to scale it up.' All districts in the Copperbelt keep reminding us about replicating, expanding, and scaling up... The EC project is one of the most wanted projects in Zambia. The Zambian Government has given high priority to $S G B V$ issues...the late President has issued a directive to all Ministries to sustain and expedite activities relating to $S G B V$... he was a gifted person, very educated and aware on these issues... the new President has pledged to support the previous President's projects. The Permanent Secretary of the Ministry of Health supports this project. ... The previous Minister of Home Affairs was very supportive, but has moved... the new Minister is a woman and I hope she will be supportive."

"We have shown it works. We need to support scale up to all areas."
"How can we ensure that this project is part of the budget?" a health official questioned. "HIVIAIDS programs are supported, and this project links to HIVI AIDS and reproductive health. Why can't this be supported?" He concluded "the information gathered must be shared. Police and health sectors can cooperate."

-Provincial health

official 


\section{ReCOMMENDATIONS}

As highlighted above, the study demonstrated that police provision of EC is feasible and that the relatively simple intervention can strengthen both health and police responses to SV. For this reason, communities, service providers, health and police officials have all called for national scale-up. The following recommendations are offered to guide the scale-up process.

\section{Ensure that a dedicated EC pill is available through the public sector}

Although EC is included in the national family planning guidelines, the public sector does not currently posses the stocks needed to scale-up the program nationally. The Population Council donated 10,000 units of the dedicated product Postinor-2 to the $\mathrm{MOH}$ for use in this project. While supplies remain in the national storehouse, they are not adequate for sustaining or expanding this intervention. Regular oral contraceptives can also be used as EC, but they require additional training to ensure the pills are properly combined.

Thus, as a prerequisite for scale-up, the $\mathrm{MOH}$ must demonstrate its commitment to providing comprehensive GBV services through the procurement and distribution of a dedicated EC product.

\section{Incorporate police provision of EC into provincial, national policies and guidelines}

The study's success is largely attributable to the active, multi-sectoral collaboration that emerged in the Copperbelt. This collaboration was institutionalized through sustained collaboration between the Ministries of Health and Home Affairs (Zambian Police Service, VSU) and the multi-sectoral "steering committee" that guided the intervention. Such structures must be replicated at provincial and national levels in order to ensure similar impact when scaled up. Provincial planning documents and other strategic plans within each province should also be revised to ensure that sufficient human and financial resources are dedicated to the program.

The relevant ministries have demonstrated exceptional commitment to ensuring integrated service delivery through the development of the "National Guidelines on the Multidisciplinary Management of Sexual and Gender-Based Violence in Zambia." ${ }^{\text {ix }}$ These guidelines include provisions to allow police provision of

\footnotetext{
ix These guidelines are currently in draft form, but are expected to be officially enacted by the end of 2009 .
} 
EC, and once adopted, will serve as a firm policy basis to replicate the program nationwide.

\section{Integrate EC services into the national VSU training curriculum, offer $\mathrm{MOH}$ certification}

Study data highlight the key role of trained VSU officers in ensuring quality EC and SV services. Service statistics indicate that Chifubu police station, which retained classroom-trained VSU officers throughout the three years of the study, provided EC and referrals more consistently than the other stations. The KAP survey also shows that officers trained under the project were significantly more likely to provide comprehensive services, such as escorting a survivor to a health facility and referring for legal advice.

To train VSU officers in the most cost-effective manner, senior police officials from the Copperbelt recommended that "these trainings should be incorporated into the syllabus of the police training college," a suggestion widely echoed by police at all levels. Such training must be conducted multi-sectorally, with active participation of the Ministry of Health and qualified health care providers, and should be integrated into other trainings on GBV currently offered to VSU officers. It is critical, however, that at least two full days be devoted specifically to the mechanics of EC provision in the context of comprehensive medical management of SV.

Upon completion of training on EC provision, VSU officers should be rigorously examined to ensure adequate knowledge acquisition. Those that achieve 90 percent or higher on the examination would then be certified as EC providers under the Ministry of Health. This national-level certification would provide trained VSU officers with the credibility and confidence needed to provide EC across the country and to share

their knowledge with supervisors and peers. It also serves as an important quality control measure, which is critical in the delivery of health services by non-health personnel.

\section{Refine the EC provision training curriculum in conjunction with the $\mathrm{MOH}$}

Because of concerns voiced over the feasibility of police provision of $\mathrm{EC}$ at the outset of this study, training of VSU officers was guided by the MOH's CBD/ EBD curriculum. This was done to satisfy the requirements established for any $\mathrm{CDB} / \mathrm{EBD}$ provider of family planning services, which covered a wide range of general and reproductive health concerns, many of which were not directly relevant to police provision of EC. 
Now that the study has demonstrated that EC can be successfully provided by VSU officers, it is recommended that the ZPS work in conjunction with the $\mathrm{MOH}$ to develop a curriculum more appropriate to the special role played by VSU EC providers. This curriculum is likely to include less emphasis on general population issues, anatomy and physiology and community health concerns such as malaria. Instead, more emphasis can be placed on counseling and intake procedures, community prevention strategies, and developing linkages with the health sector.

\section{Integrate EC into the national training curriculum for all police officers}

An important lesson learned in the course of implementation was that all officers in the police station need to be made aware that EC was available in the station. Such awareness was necessary to ensure that the front desk officers, who receive all reports to the station, refer cases to VSU officers in a timely and consistent manner. This is especially important during night, weekend and public holiday shifts, when VSU officers are not on duty and must be called in to attend to the survivor.

VSU officers trained under the study unanimously concurred that "this training should be extended to other officers in the force-officers at the inquiries or front desk-because they are the ones who first come into contact with these victims, and sometimes the VSU officer is not available so they will also be able to attend to this victim properly."

While the training for these other officers need not be as comprehensive as for the EC providers, or include certification, it is critical that they are adequately able to respond to the basic needs of survivors and ensure that they are immediately referred for medical care and forensic evidence collection.

\section{Assign dedicated health sector staff to support police EC providers}

At the outset of the study, the district RH coordinator was assigned to support police provision of EC through supervisory visits, stock resupply, data monitoring and technical support. The RH coordinator, however, was unable to perform these duties due to illness and project staff assumed this role. While this worked well throughout the study period, it is not a sustainable strategy.

Each district and provincial health team must designate staff who are responsible for supporting police provision of EC. At the provincial level, a focal point is necessary to help ensure policy-level coordination and collaboration. At the district level, staff should be given the responsibility of supporting all trained VSU EC providers. Recognizing the country's human and financial resource 
constraints, it is likely that these duties will be added to an existing employee's scope of work. Nonetheless, $\mathrm{MOH}$ management should ensure that sufficient staff time is dedicated to supporting police EC provision. Such active health sector involvement is critical for maintaining the quality and safety of EC services and is a prerequisite for scale-up.

\section{Develop innovative approaches to overcoming transport constraints}

Limited transportation was consistently identified by all participants as an important constraint to providing comprehensive GBV services. Transportation serves as a barrier for the community to seek care, prevents police from consistently accompanying survivors to the health facility, undermines the police's ability to investigate crime scenes, and limits utilization of follow-up care. Transport difficulties arise from too few operable vehicles available to VSU officers and expensive or irregular public transportation, especially in rural areas.

Innovative strategies are needed to overcome this barrier to care-seeking. Providing vehicles to VSU officers across the country is most likely not feasible in the short- or medium-term. Instead, police must develop alternatives, such as organizing voucher systems to access public transportation or supplying police with low-cost, locally manufactured bicycles. Both strategies have proven successful in other settings, but creative, Zambia-specific solutions are also necessary. 


\section{Appendix 1: Training Schedule for VSU Officers}

\begin{tabular}{|c|c|c|c|c|c|c|}
\hline TIME & MONDAY & TUESDAY & WEDNESDAY & THURSDAY & FRIDAY & SATURDAY \\
\hline $\begin{array}{l}08: 30- \\
09: 30\end{array}$ & $\begin{array}{l}\text { Registration } \\
\text { Housekeeping } \\
\text { Pretest } \\
\text { Opening remarks }\end{array}$ & $\begin{array}{l}\text { Housekeeping } \\
\text { Functions of VSU } \\
\text { in GBV response } \\
\text { (VSU head) } \\
\text { Functions of } \\
\text { district health team } \\
\text { in GBV response } \\
\text { (health official) }\end{array}$ & $\begin{array}{l}\text { Housekeeping } \\
\text { Elements of } \\
\text { Quality of Care }\end{array}$ & $\begin{array}{l}\text { Housekeeping } \\
\text { Gender-Based } \\
\text { Violence (GBV) } \\
\text { in Zambia: } \\
\text { definitions, laws, } \\
\text { prevalence and } \\
\text { perceptions }\end{array}$ & $\begin{array}{l}\text { Housekeeping } \\
\text { Interpersonal } \\
\text { communication } \\
\& \text { methods of } \\
\text { communication }\end{array}$ & $\begin{array}{l}\text { Housekeeping } \\
\text { Creating } \\
\text { community } \\
\text { awareness: role } \\
\text { plays }\end{array}$ \\
\hline $\begin{array}{l}09: 30- \\
10: 30\end{array}$ & $\begin{array}{l}\text { Introduction to } \\
\text { VSU EC training }\end{array}$ & $\begin{array}{l}\text { Characteristics of } \\
\text { EBDs } \\
\text { Group work \& } \\
\text { presentations }\end{array}$ & $\begin{array}{l}\text { Family planning } \\
\text { methods \& how } \\
\text { they work }\end{array}$ & $\begin{array}{l}\text { Rights of a GBV } \\
\text { survivor }\end{array}$ & $\begin{array}{l}\begin{array}{l}\text { General } \\
\text { counseling } \\
\text { principles }\end{array} \\
\text { Counseling } \\
\text { special groups }\end{array}$ & $\begin{array}{l}\text { Group wrap-up } \\
\text { discussions }\end{array}$ \\
\hline $\begin{array}{l}10: 30- \\
11: 00\end{array}$ & TEA BREAK & TEA BREAK & TEA BREAK & TEA BREAK & TEA BREAK & TEA BREAK \\
\hline $\begin{array}{l}11: 00- \\
12: 00\end{array}$ & $\begin{array}{l}\text { Zambian } \\
\text { Population } \\
\text { Dynamics }\end{array}$ & $\begin{array}{l}\text { Concept, rationale } \\
\text { \& benefits of family } \\
\text { planning (FP) } \\
\text { Group discussions }\end{array}$ & $\begin{array}{l}\text { EC Pill: how it } \\
\text { works, safety, } \\
\text { side effects \& } \\
\text { effectiveness }\end{array}$ & $\begin{array}{l}\text { Referring a GBV } \\
\text { survivor }\end{array}$ & $\begin{array}{l}\text { Counseling } \\
\text { Role plays }\end{array}$ & Post test \\
\hline $\begin{array}{l}12: 00- \\
13: 00\end{array}$ & $\begin{array}{l}\text { Zambia Family } \\
\text { Planning Policy }\end{array}$ & $\begin{array}{l}\mathrm{FP} / \mathrm{EC} \text { rumors \& } \\
\text { misinformation }\end{array}$ & $\begin{array}{l}\text { EC eligibility } \\
\text { criteria } \\
\text { Issuing and } \\
\text { recording EC } \\
\text { provision } \\
\\
\text { Relationship of } \\
\text { EC to other FP } \\
\text { methods }\end{array}$ & $\begin{array}{l}\text { Discussion on } \\
\text { participants' } \\
\text { expectations from } \\
\text { health facility visit }\end{array}$ & & $\begin{array}{l}\text { EC Distribution } \\
\text { Closing remarks }\end{array}$ \\
\hline $\begin{array}{l}13: 00- \\
14: 00\end{array}$ & LUNCH BREAK & LUNCH BREAK & LUNCH BREAK & LUNCH BREAK & LUNCH BREAK & LUNCH BREAK \\
\hline $\begin{array}{l}14: 00- \\
15: 00\end{array}$ & $\begin{array}{l}\text { Introduction to } \\
\text { employer-based } \\
\text { distribution } \\
\text { (EBD) concept } \\
\text { \& functions } \\
\text { in relation to } \\
\text { Reproductive } \\
\text { Health (RH) }\end{array}$ & $\begin{array}{l}\text { Group work and } \\
\text { presentations on } \\
\text { RP/EC rumors \& } \\
\text { misinformation }\end{array}$ & $\begin{array}{l}\text { EC recording, } \\
\text { reporting \& record } \\
\text { keeping } \\
\text { Re-ordering EC }\end{array}$ & \multirow[t]{3}{*}{$\begin{array}{l}\text { Participants visit } \\
\text { health facility }\end{array}$} & $\begin{array}{l}\text { Principles } \\
\text { for creating } \\
\text { community } \\
\text { partnerships }\end{array}$ & \multirow[t]{4}{*}{ End of training } \\
\hline $\begin{array}{l}15: 00- \\
16: 00\end{array}$ & $\begin{array}{l}\text { Functions in } \\
\text { relation } \mathrm{RH}\end{array}$ & $\begin{array}{l}\text { Anatomy and } \\
\text { functions of } \\
\text { female \& male } \\
\text { reproductive } \\
\text { organs }\end{array}$ & $\begin{array}{l}\text { Sources of EC in } \\
\text { Zambia }\end{array}$ & & & \\
\hline $\begin{array}{l}16: 00- \\
16: 30\end{array}$ & $\begin{array}{l}\text { Other functions of } \\
\text { EBDs }\end{array}$ & $\begin{array}{l}\text { Ovulation, } \\
\text { menstrual cycle \& } \\
\text { conception }\end{array}$ & $\begin{array}{l}\text { Other prophylaxes } \\
\text { available at health } \\
\text { facility: prevention } \\
\text { \& treatment of } \\
\text { STIs, HIVIAIDS }\end{array}$ & & $\begin{array}{l}\text { Developing } \\
\text { community } \\
\text { awareness } \\
\text { outreach plans }\end{array}$ & \\
\hline $\begin{array}{l}16: 30- \\
18: 00\end{array}$ & $\begin{array}{l}\text { Facilitators } \\
\text { meeting }\end{array}$ & $\begin{array}{l}\text { Facilitators } \\
\text { meeting }\end{array}$ & $\begin{array}{l}\text { Facilitators } \\
\text { meeting }\end{array}$ & $\begin{array}{l}\text { Facilitators } \\
\text { meeting }\end{array}$ & $\begin{array}{l}\text { Facilitators } \\
\text { meeting }\end{array}$ & \\
\hline
\end{tabular}




\section{Appendix 2: Client Screening Checklist for Police Provision of EC}

- Complete all questions to determine a client's eligibility for EC.

- Place all completed forms in the EC storage container. They will be collected by the district family planning coordinator.

Facility:

Date form completed

VSU Officer

Case O.B. Number

Client's Age

\begin{tabular}{|l|l|l|l|}
\hline 1. & Was the client raped/ defiled? & $\begin{array}{l}\text { Yes } \\
\text { (go to 2) }\end{array}$ & $\begin{array}{l}\text { No } \\
\text { Client not eligible }\end{array}$ \\
\hline 2. & Did the assault involve penetrative sex? & $\begin{array}{l}\text { Yes } \\
\text { (go to 3) }\end{array}$ & $\begin{array}{l}\text { No } \\
\text { Client not eligible }\end{array}$ \\
\hline 3. & Did the assault occur within the past 72 hours? & $\begin{array}{l}\text { Yes } \\
\text { (go to 4) }\end{array}$ & $\begin{array}{l}\text { No } \\
\text { Client not eligible }\end{array}$ \\
\hline 4. & Has the client had her first menstrual period? & $\begin{array}{l}\text { Yes } \\
\text { (go to 5) }\end{array}$ & $\begin{array}{l}\text { No } \\
\text { Client not eligible }\end{array}$ \\
\hline 5. & Does the client want to prevent pregnancy? & $\begin{array}{l}\text { Yes } \\
\text { (go to 6) }\end{array}$ & $\begin{array}{l}\text { No } \\
\text { Client not eligible }\end{array}$ \\
\hline
\end{tabular}

If client answered "YES" to questions 1-5, she is eligible for EC. Proceed. If client answered "No" to ANY of the questions above, she is not eligible. Stop.

6. Is the client currently pregnant?

\begin{tabular}{l|l}
$\begin{array}{l}\text { Yes } \\
\begin{array}{l}\text { Client not } \\
\text { eligible }\end{array}\end{array}$ & $\begin{array}{l}\text { No } \\
\text { (go to 7) }\end{array}$ \\
\hline
\end{tabular}

If the client's pregnancy status is unclear, EC may still be given, but with the explanation that it will not work if she is already pregnant and will not harm the fetus.

\begin{tabular}{|l|l|l|l|} 
7. & $\begin{array}{l}\text { Was the client's last menstrual period less than } 4 \\
\text { weeks ago? }\end{array}$ & $\begin{array}{l}\text { Yes } \\
\text { (go to 8) }\end{array}$ & $\begin{array}{l}\text { No } \\
\text { Do not dispense }\end{array}$ \\
\hline $\begin{array}{l}\text { 8. } \\
\text { Was her period normal in both its length and } \\
\text { timing? }\end{array}$ & Yes & $\begin{array}{l}\text { No } \\
\text { Do not dispense }\end{array}$ \\
\hline
\end{tabular}

*Adapted from: Resources for Emergency Contraceptive Pill Programming: a Toolkit. PATH: 2004 



\section{(2) Population Council}

\section{Sida}

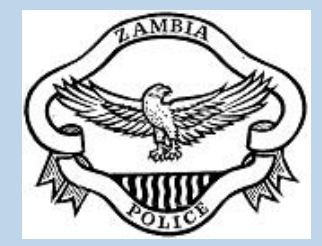

Population Council, Zambia

La Belva Court, Plot 417

Chindo Road, Kabulonga

Lusaka 10101

Zambia

Tel: +260-211-262-665/6 